\title{
Towards a transformed library and information sector in South Africa: rethinking roles
}

\author{
Gavin Davis \\ Library and Information Science, University of the Western Cape \\ gdavis@uwc.ac.za
}

Received: 10 May 2009

Accepted: 6 November 2009

\begin{abstract}
The paper examines the current state of libraries in South Africa. It draws on the state's role in the provision of library services since South Africa became a democracy in 1994. There seems to be a worrisome aspect that the place of public libraries within local and provincial governments is in a state of uncertainty. Hence the urgency with which the National Council for Library and Information Services (NCLIS) is approaching the problem by having appointed a technical team to develop broad legislative and policy guidelines for the transformation of the library and information services (LIS) sector. The focus of the paper is rather on an argument for a rethink of the role of libraries and librarians within the local and provincial context. It is the author's contention that the services of a library should contribute towards the quality of life, that is, the library should play a role in education, the promotion of moral values, the eradication of illiteracy, the alleviation of poverty and assisting in the quest for knowledge and the promotion of democracy in society. The whole notion of democracy needs to be deconstructed. Certain objectives need to be set in order to attain this aim of the library, namely, the library should foster and provide certain facilities for the development of individuals and groups at all levels of education, for example, a study area and an activity room or auditorium; the library should be accessible to the user to fulfil his/her information needs, in the quickest possible time; the library should be a main centre for the promotion and appreciation of all arts so that cultural life can be enriched; the library should play a positive part in the encouragement of active usage of leisure and recreation time. This calls for a well informed and empowered library professional. Although the concept of library professional is used somewhat loosely here, library workers in general should not be excluded when library services are rendered.
\end{abstract}

Keywords: Transformation; public libraries; library and information services (LIS); democracy; library professional

\section{Introduction}

Political change in South Africa, which is a country in transition, has invariably implied a change to library structures. Libraries cannot be excluded from the democratic process, which requires:

- Free movement of information flow;

- Quick and easy access to information; and

- Wide use of updated information for the needs of education, science, culture and economics.

To achieve the ultimate objective of development in a community, libraries have to be included, precisely because of their connection between people and information. As Kantumoya (1992), quoted by Uhegbu (2001:242), has argued:

People will not be able to get their due as citizens of the present day society unless they have a continuous access to information which will guide them through and where necessary the advice to help them translate that information into action.

Historically, libraries have come into being with very noble roles. Pinhey (2003) states that in the United States of America (USA), for example, libraries were established to safeguard democracy. In many other countries they are a symbol of important social changes. In some regions, the public library as an example, like the church and the school, is part of the local landscape. There are many examples of public libraries becoming a natural medium of social inclusion (Suaiden 2003:382). This author further points out that when a library opened its doors to the public, it became a focal point, a reference point, for the community in which it was situated, thereby facilitating the introduction of books and reading into people's daily lives (Suaiden 2003:379). This was a fundamental function of the public library. One may perhaps argue that the primary purpose of a public library is to provide resources and services in a variety of media to meet the needs of individuals and groups for education, information and personal development including recreation and leisure. The public library therefore has an important role to play in the development and maintenance of a democratic society by giving the individual access to a wide and varied range of knowledge, ideas and opinions (Gill, et al., 200I:2). However, has the public library achieved this role?

I. Gavin Davis $(\mathrm{PhD})$ is the Departmental Chair, Library and Information Science, University of the Western Cape, Bellville, South Africa. 


\section{Public libraries: state agents?}

The traditional public library in Africa has failed to make any substantial impact on development. From the available literature it is clear that the model of public library services imported from the West hardly took into consideration local needs and the socio-political situation of African peoples (Issak 2002:330). It seems therefore that the traditional public library model was inadequate as regards meeting the information needs of African peoples. However, another view holds that public libraries provide access to knowledge, information and works of imagination through a range of resources and services. The public library is equally available to all members of the community regardless of race, nationality, age, gender, religion, language, disability, economic and employment status and educational attainment (Gill et al., 200 I:I-2).

Although people of all classes have access to public libraries in all communities, there is unfortunately still an unequal distribution of resources. It is also argued that public libraries are generally stocked with literature that is usually foreign, outdated and irrelevant to the information needs and interests of the people expected to use them (Okiy 2003:127). To Okiy (2003) the public library should discard its traditional docile role as repository of knowledge and ideas and rise to the challenge that any rapid modernization process entails. From these views it seems public library services in Africa have for a long time operated without fully taking into consideration the needs of the people they are meant to serve. Could the same argument hold for South African public libraries? Suaiden (2003:I) suggests that public libraries are often perceived as elitist institutions serving only the most educated living in cities and ignoring the rural people. According to Suaiden, public libraries became viewed from a social perspective as elitist places, book depositories, or somewhere to do schoolwork. Those problems prompted the emergence of a conflict of views between the information professional and the wider community. Suaiden furthermore argues that librarians considered for a long time that the main purpose of a library was to preserve its collection, and that made the circulation and dissemination of books difficult. This notion promoted the creation of "useless" [public] libraries (Suaiden 2003:379). However, with the emergence of a new society, the so-called information society, the preservation paradigm seemed to dissipate. This new society essentially demonstrates that information generates power, especially when it is disseminated in a short space of time or in real time (Suaiden 2003:379). With the emergence of the information society, it became more important for public libraries to play a vital role in enabling people to use information communication technologies (ICTs).

There is little evidence to suggest that public libraries have put programmes in place to uphold the Batho Pele principles. Batho Pele literally means "people first". The idea of Batho Pele is to form partnerships between government and civil society. This calls for active community participation in whatever programmes of action. The South African Government's idea of partnership building goes across services such as education, health, housing, policing and general public service delivery including library services. The White Paper for Transforming Public Service Delivery for instance put forward eight principles or guidelines for Batho Pele:

- Consultation;

- Service Standards;

- Courtesy;

- Access;

- Information;

- Openness and transparency;

- Dealing with complaints; and

- Giving best value.

Indeed public libraries are often perceived as bureaucratic institutions. Martin (1990:II) for instance pointed out that despite being an integral feature of society public libraries continue to be institutionalized. The assertion here is that despite public libraries being institutions, librarians need to go beyond the physical boundaries to render services to the general public. In other words it should not only be expected of people to frequent the library, but librarians need to make every effort to make people aware of the services of the library.

More than a decade ago, certain statements were made in favour of the public library system in the Western Cape Province. The Western Cape Public Library Services in 1995, according to Van Der Merwe (1995:12) stated that its mission was:

... to improve the quality of life of all the people of the Province by enabling local authorities to provide a public library service to their communities.

This mission statement can be translated into:

- a support system for local authorities in financial terms to address past imbalances in the provision of library services;

- a support system for all public librarians by the provision of an information system and professional guidance and training;

- the provision of library materials in various forms and formats to meet informational, recreational and educational needs of each community; and 
- the promotion and the use of library facilities and materials.

Some attention has been given to policy formulation to make the above a reality. However, there still seems to be an uncertainty in terms of responsibility for the provision of library services in the country as a whole, as well as in the provinces. Although policy documents have appeared since South Africa's first democratic elections, very little has been written on libraries. Hopefully the National Council for Library and Information Services (NCLIS) will give more serious thought to public library matters. An area which this Council is currently concentrating on is a national transformation charter for library and information services. This charter is however not complete but in its sixth draft. It remains to be seen when the charter will be tabled at the South African parliament

\section{Moral renewal}

There is a growing concern in South African Society today of the increase in moral decay. This moral decay has been recognized as early as 1998 by former President Nelson Mandela when he invited religious and political leaders to a Moral Summit in Johannesburg to address the issue. After much deliberation the Moral Regeneration Movement (MRM) was established. The South African government is strongly advocating for a moral renewal acknowledging that “... functional, vibrant and dynamic institutions, individuals and groups and not broken family structures, dysfunctional institutions, immoral individuals and groups" are needed (Balindlela 2004). In a statement on moral regeneration the former minister of Arts, Culture, Science and Technology, Dr Ben Ngubane outlined the government's commitment to “... hold a consultative summit on the issue of moral renewal in our country as a matter of urgency" (Ngubane 2002).

This summit was held on 18 April 2002 at Waterkloof Airbase in Pretoria. At the summit the idea was to build a society in which the moral fibre of society would be restored. It was important to promote people's dignity, equality, freedom and security as enshrined in South Africa's Bill of Rights. The notion of morality would involve values and standards to be shared by groups. Hopefully this would bring about “... beliefs about what is good and right that holds together a community with a shared history" (Ngubane 2002). To bring the mentioned issues to realization the South African Government has placed a high premium on service delivery by public institutions.

The MRM has received some criticism. While immorality does not only pertain to crime, it appears that the campaign for moral regeneration was “... strongly linked, at its inception, to a concern about crime in South Africa” (Rauch 2005). She argues that the movement failed to draw clear demarcation lines about what is immoral behaviour. Despite these criticisms I will discuss moral values within the context of anti - social behaviour and the role of public libraries. Anti-social behaviour has a lot to do with developmental issues. At this point it is useful to revisit the concept of development.

\section{Development revisited}

The then Premier of the Eastern Cape Province in his opening speech at the moral regeneration summit through education in East London remarked, “... education was used by the apartheid regime as a launching pad for institutionalization of apartheid ideology ..." (Balindlela 2004). The ex-Premier continued that education was also used to exclude the majority of South Africa's people from developing socially and economically but that,

$\ldots$ it is through education that we can be able to reverse the apartheid effects that are haunting us from each

and every corner and nook of this country and at every level of our societal structures

Moral regeneration has the aim of using education as a moral formation both in theory and practice. Do libraries play a meaningful role in this moral formation? I want to briefly discuss public / community libraries as an example.

\section{Community libraries: people driven?}

It is important that librarians, especially those who work with significant numbers of young patrons and their families make their voices heard and their libraries' services visible throughout the community (Feinberg \& Feldman 1996:25).

It is the library's role to support lifelong learning and underpinning the move towards increased social inclusion and economic regeneration. Libraries should be resources that are easily accessible and available and which offer a nonjudgmental environment for people of all backgrounds (Feinberg \& Feldman 1996:26). Rikowski (2002:I) suggests that public libraries are often seen as havens, places that offer a sense of well being, community centres, safe places, and exhibition centres, places to read, think, discover, learn and explore different ideas. Andersen (1998) on the other hand argued that public libraries have traditionally been seen as depots for acquiring and housing of collections, which they make accessible to interested people.

The public library of the twenty first century according to Gericke (1997:2) will have to serve those people who were up to now the "unserved" if it wants to have any right to existence. Black and Muddiman (1997:53) were of the opinion that for most progressive librarians, negative arguments of libraries, pointed towards the need for a new culture of public librarianship focused around a more 'community oriented' service. How can the public library become more community oriented? 
Feinberg \& Feldman (1996:13) argue that library staff must embrace the belief that all children and their families are library customers. These users are of primary importance. Librarians should therefore form partnerships with parents, early care and education providers, and other community-based agencies. Since families are the focus of family centres, it is apposite that the exploration of libraries as family centres begin with a brief enquiry into some issues surrounding 'the family'. A simple unambiguous and useful definition of the family is surprisingly difficult to achieve. The word 'family' has something to do with marriage and parenthood and that these two terms themselves have something to do with, respectively, the relationships between adults and the relationships between adults and children, these two sets of relationships being focused on something that may be called a home or household (Stones 1994: I).

Thus librarians working with different kinds of people in the community, require an understanding of the unique reality of each family structure. Librarians need to recognize that there is considerable diversity in the patterns of roles and relationships, differences in class, culture, beliefs, and value within families.

\section{Community defined}

Uhegbu (2001: 238) citing Anyanwu (1992) outlines six basic characteristics with which a community can be identified:

- Shared territory within which the members live and develop the ways of life that give the community an identity;

- Shared beliefs, which are nurtured and cherished by the people in the development of their common ideals, objectives, attitudes and values;

- Shared bonds of fellowship, which demands obligations from the citizens, and the conferment of benefits to them;

- Set standards and patterns of behaviour which bring every citizen to conform to norms and values; it also helps to develop intimacy of relationships and bond of love and association;

- A common culture which is the aggregate of the social, ethical, intellectual, artistic governmental and industrial attainments of a community; it includes the ideas, traditions, customs, usages, institutions, associations and material objective characteristics of such a community; and

- Common administration where there is a common plan, a process involving accountability and responsibility for the good governance of such a community.

Although not all of these characteristics may relate to the public or community library they certainly involve needs which may be common. Some of these needs may also reflect common library needs. There is a tendency in the post apartheid South Africa to express these library needs as:

- Provision of study facilities as the majority of the users does not have study facilities inclusive of electricity or privacy at home;

- Provision of Information Technology e.g. Internet, Word Processing facilities;

- Provision of Computer and Information literacy skills;

- Provision of Adult Basic Education and Literacy programmes; and

- Provision of community based activities, focusing on educational support and arts \& cultural development

These library needs call for a different or revised model of library services to the different communities. Atuti (200I) posits that the aims of a community library should be:

- To encourage the community to identify its information needs and to involve its participation in the establishment of such new sources of information for their use and mutual benefit;

- To be an advocate for society's appreciation of the role and importance of library and information services in modern socio-economic, cultural and political life;

- To develop partnerships and strengthen co-operation with the community, and to utilize available community resources (funds, buildings) through mobilization; and

- To supplement government efforts in providing library and information services in rural areas.

\section{Rethinking the role of librarians}

If one assumes that librarians and libraries build community, this calls for a rethink on the library practitioner's role within the community and society. One of the public librarian's key roles is to provide information and referral community services to patrons. This information is found not only through manual and online services, but to be accurate and effective, must be supplemented with personal knowledge of existing community resources (Feinberg \& Feldman 1996:13).

Library personnel need to act as agents for grooming and nurturing African communities towards their renaissance (Banach 1988:10). Librarians need to become more imaginative and willing to break new ground. The professional skills and attitudes required of librarians also need to change if services are to be in line with change. The librarian/worker needs to be involved with, and be a part of, the community if he/she is to be accepted by the community.

According to Banach (1988:10) the "barefoot librarian is seen as an alternative to the professionally qualified with appropriate skills in teaching, literacy, design and production of audio-visual instruction, with a training in oral literature, 
and techniques of acquiring and processing eyewitness information and applying new information to the development and improvement of life appropriate to a particular community."

South Africa has diverse communities with different cultures. Affirmative action, alleviation of poverty, eradication of homelessness, unemployment and dealing more effectively with HIV/AIDS are some of the main concerns of the South African government. These concerns are changing the landscape of community building. The librarian's role is to be aware of happenings in the community and if needs be attend community meetings, listen and participate in offering some solutions. Information professionals are all aware that, in order to serve the needs of their users, readers and customers, it is essential to work with others.

The place of the public library within the local government is facing uncertainties. Librarians have to act upon these uncertainties in promoting libraries to their communities in practical ways. While always an important part of family and community life, today's libraries have an even greater potential to play a significant role in responding to and meeting the broader needs of children, youth and families in communities.

\section{A rethink on socio-economic issues}

If especially black South Africans were more than overjoyed with the ANC victory in the April 1994 national and subsequent regional and local elections and perhaps naively thought that this would signal the end of hardships and poverty, it did not take long for disillusionment to surface. As Moller (1997:7), puts it “... post election happiness showed that the political aspirations of the formerly disenfranchised had been fulfilled, [however] the subsequent drop in happiness and satisfaction eighteen months later, indicated that the material aspirations fuelled by the election promises of 'a better life for all' had still to be met." This is despite the ANC's promise to “... reduce and eliminate the massive inequalities established by apartheid by making resources available for the advancement of those oppressed and kept back in the past by racial discrimination and gender oppression" (African National Congress 1994:3).

Not too long ago, Ebrahim Rasool, the then Minister of Finance and Economic Development and ex- Premier of the Western Cape Province, made a similar remark, when he stated that the government is committed to a "...society where women are treated equally, where children are protected, where our youth are nurtured, where the aged are cared for, where the disabled are valued... and all race groups can declare that indeed [the Western Cape] Province is home for all" (Western Cape Provincial Government 2004: 3). Little evidence of this having materialised is available. Hopefully, a valuable resource such as the public library can be part of this commitment.

\section{Social responsibility}

Librarians need to build a healthy, integrated level of service to families and children. They provide the foundation for developing library relationships with other community agencies, which can be viewed as part of a continuum ranging from networking to collaboration. Within this framework, the library can expand its program and service opportunities and become fully integrated into the fabric of community life (Feinberg \& Feldman 1996:33). Librarians, who are perceived to be the custodians of libraries, have to:

- Provide a system of care that promotes family well-being, health and stability;

- Make services readily available to all parents at the earliest opportunity;

- Provide intervention, in the form of information, prior to the manifestation of problems;

- Emphasize family-identified strengths, skills and abilities;

- Assist parents in identifying and clarifying their own values;

- Preserve families by helping them acquire the resources needed to care for their children; and

- Help parents develop skills so they can use information and services effectively without the need for institutional support.

\section{The future: some considerations}

The need for change, given apartheid's stranglehold, in the South African Library System and, with it, the promotion of change in the wider society is self-evident. Libraries can help to bring about such change by the provision of imaginative and socially responsive programmes that seek to increase the range of individual opportunities as well as enhancing the social infrastructure.

Democratisation of the state and society can only succeed if communities are empowered by effective distribution and use of information conducive to growth and development. Therefore libraries should extend library services to all. In particular, emphasis should be on services to previously marginalised communities, especially in rural areas, townships and informal settlements. Libraries should strive to become learning centres for life long learning and development. Guidance is the essence of service rendering and service orientation.

SA Jnl Libs \& Info Sci 2009, 75(2) 
Technological changes and the fact that South Africa is becoming an Information society, make it imperative that library staff be given opportunity to attend continuing education programmes. The library as centre for the generation of recorded knowledge can only provide services conducive to growth if the staff is well informed of global information issues. Continuing education programmes can range from basic computer literacy skills to human resource management skills. It must be borne in mind that librarians as well as library assistants need to be updated on a regular basis of issues, which affect their work.

Provincial or local government should have the responsibility of establishing a system whereby staff is allowed to attend continuing education programmes, without disrupting the day-to-day functions at their libraries. This calls for adequate staffing at these libraries. The divide between theory and practice should be narrowed, so that graduates should not find a hostile environment, given their theoretical backgrounds. Practical fieldwork by students should be a compulsory aspect entrenched in the curricula of Library and Information Science departments/schools, so that practising librarians could evaluate the performances of students, in conjunction with lecturers. On the other hand, practising library workers could attend summer or winter schools at tertiary institutions. These could be in the form of information literacy skills, Internet searches and other skills for capacity building.

Library material selection policies should be reviewed on a regular basis. Community needs are to be taken into account and determined by scientific investigation, by recognised methodologies. Library authorities should liaise with academic institutions in this regard.

Library services should be more directly relevant to the needs and interests of the masses. This argument is further supported by Feinberg \& Feldman (1996) that libraries are essential partners in interagency collaborations that affect policies and services for families within communities. Increasing emphasis should be placed on advocacy, community action and community education. Individuals and groups can therefore be assisted with daily problem solving and with participation in the democratic process. Volunteers can provide services that concentrate on the needs of those who do not have ready access to other sources of assistance and on the most important problems that people have to face, problems to do with their homes, their jobs and their rights.

Communication between library staff and the families in the community is particularly important. Librarians should consider forming partnerships with parents, early care and education providers, and other community-based agencies. The coordination and coalition between libraries, families, community agencies and other information organizations would end passivity and neutrality of libraries and committed participation in the real world outside libraries. Barefoot librarians can provide for their communities in a significant way, with the help of agencies and educational organizations.

Through the development of coalitions and networks, librarians can expand their horizons, become informed professionals, and be alerted to trends in youth services, and early childhood and parent education. Feinberg \& Feldman (1996) give the following reasons why the integration of library services with the community and other agencies will increase the library's gain. Parents and professionals will learn:

- To recognise the library's ability to organise and disseminate information to its community;

- To understand the role of the library in providing free access to information;

- To look towards the library a primary community center for serving families and young children;

- To place the library and the children's librarian in a leadership role in advocating for youth and family services; and

- To appreciate the library's role in sharing community resources, building a democratic nation, and beginning the lifelong learning process.

Some programmes for cooperation may be some of the following:

- Child care and Day care facilities;

- Youth Clubs;

- Public health programmes;

- Job creation programmes;

- Local agencies involved in victims of abuse;

- Parent educator's network or parent resource centre;

- Church and hospital information services;

- Organization serving teen mothers;

- University development programmes;

- Library services to house-bound patients;

- Library services on farms and rural areas;

- Local history collections;

- Community information and referral databases;

- Literacy classes;

- Volunteer programmes for library support; 
- Local business and entrepreneurial Forums;

- Small business Corners;

- Revisit of Vegetable garden initiatives;

- Book talk groups for moms and toddlers;

- Book circles;

- Cultural clubs;

- Cooperation with school libraries; and

- Shared collection development with other library and information services.

\section{I Conclusion}

If one takes into account the discrepancies of the past, where public libraries reserved for whites had more library resources than those allocated for blacks, clear criteria should be set for determining information and reading needs. Library managers will have to address illiteracy issues and lobby for the establishment of infrastructures for the promotion of literacy. Library facilities like auditoriums can be made available for training trainers of basic adult education. The library can in this sense become a centre where people can empower themselves. Especially the unemployed can make use of the library's materials for information geared towards self-reliance. Librarians should therefore strive to change the image of libraries as "storehouses of information" to deinstitutionalized agencies that involve families, the community and other role players.

\section{References}

African National Congress. 1994. The reconstruction and development programme: a policy framework. Johannesburg: African National Congress

Andersen J. 1998. Literacy in Libraries: Discussion Group Paper on Social Responsibilities. [Online]. http:/www.ifla.org. Accessed I5 April 2008.

Atuti, R. M. 200I. Managing adaptation of buildings to library use: a case study of community libraries in Kenya. Library Review, 50(5):23I-236

Balindlela, N. 2004. Opening speech on the occasion of the moral regeneration summit through education. [Online]. http:// www.info.gov.za/speeches/2004/04 I I08I5451007.htm. Accessed I 3 September 2008.

Banach, E. 1988. The role of the public library in a changing society. Artes Natales, 7(I I):5-I I.

Black, A. \& Muddiman, D. 1997. Understanding Community Librarianship: the Public Library in Post-modern Britain. Brookfield, Vt.: Ashgate Publishing.

Caffentzis, G. 2000. The World Bank and education in Africa. In: a Thousand flowers: social struggles against structural adjustment in African Universities. Federici, S, Caffentzis, G \& Alidou, O. (eds.) Irenton, N.J.: Africa World Press, pp. 3 - I8.

Federici, S \& Caffentzis, G. 2000. 1958 - 1998: chronology of African university students' struggles. In: a thousand flowers: Social struggles against structural adjustment in African Universities. Federici, S, Caffentzis, G \& Alidou, O (eds). Irenton, New Jersey: Africa World Press, pp. 115 - 150.

Federici, S, Caffentzis, G. \& Alidou, O (eds.). 2000. A thousand flowers: social struggles against structural adjustment in African Universities. Irenton, New Jersey: Africa World Press.

Feinberg S. \& Feldman S. 1996. Serving families and children through partnerships. New York, London: Neal-Schuman.

Gericke, E.M. 1997. Serving the unserved in the year 2000. Proceedings of the $63^{\text {rd }}$ IFLA General conference, August 31 to September 5, 1997. [Online]. http://www.ifla.org/IV/ifla63/63gere.htm. Accessed 3 August 2008.

Gill, P., Clubb, B., Glashoff, I., Hassner, K., Hayrapetian, N. \& Pestell, R. 200I. The public library service: IFLA/UNESCO guidelines for development. Munchen: K.G. Saur.

Issak, A. 2002. Public libraries in Africa: a report and annotated bibliography.

Journal of Documentation, 58(3):330-332.

Martin W.J. 1990. Community librarianship: changing the face of public libraries. London: Bingley.

Moller, V. 1997. Quality of life in South Africa: post-apartheid trends. Bulletin, 4(2):6-9.

Närman, A. 1995. Education and nation building in Kenya: perspectives on modernization, global dependency and local development alternatives. Göteborg: Vasastadens Bokbinderi.

Ngubane, B. 2002. Moral regeneration summit. [Online]. http://www.dac.gov.za/news/speeches/2002_04_I6.htm. Accessed 2I September 2008.

Okiy, R.B. 2003. Information for rural development: challenge for Nigerian rural public libraries. Library Review, 52(3): I26-I3। .

Pinhey, L. 2003. Libraries and democracy. [Online]. http://www.michaellorenzen.com/eric/democracy.html. Accessed 24 August 2008.

Rauch, J. 2005. Crime prevention and morality: the campaign for moral regeneration in South Africa. [Online]. http:// www.iss.co.za/pubs/Monographs/Nol I 4/Conclu.htm. Accessed 2 I September 2008.

Rikowski, R. 2002. What does the future hold for public libraries? Information for Social Change, 14 (Winter2001/2002):8-I7.

Stones, C. 1994. Focus on families: family centres in action. London: Macmillan.

Suaiden, E.J. 2003. The social impact of public libraries. Library Review, 52(8):379-387.

Uhegbu, A.N. 200I. Deterrents to information services for community development. Library Review, 50(5):237-242.

Van Der Merwe, F. 1995. Die Biblioteekdiens: 'n nuwe bedeling. Cape Librarian, 39(I):I0-I3.

Western Cape Provincial Government. 2004. Budget speech 2004. Cape Town: Western Cape Provincial Treasury.

SA Jnl Libs \& Info Sci 2009, 75(2) 